\title{
Use cases for COVID-19 screening and surveillance with rapid antigen-detecting tests: a systematic review
}

\section{Authors:}

Apoorva Anand*, ${ }^{*}$ Jacob Bigio*, 1,2 Emily MacLean*, ${ }^{2,3}$ Talya Underwood, ${ }^{4}$ Nitika Pant Pai, ${ }^{1,5}$ Sergio Carmona, ${ }^{6}$ Samuel G. Schumacher, ${ }^{6}$ Amy Toporowski ${ }^{\dagger 6}$

1. Research Institute of the McGill University Health Centre, Montreal, Canada

2. McGill International TB Centre, Research Institute of the McGill University Health Centre, Montreal, Canada

3. Department of Epidemiology, Biostatistics and Occupational Health, McGill University, Montreal, Canada

4. Anthos Communications, Northwich, United Kingdom

5. Division of Clinical Epidemiology, Department of Medicine, McGill University

6. FIND, Geneva, Switzerland

* Authors contributed equally

${ }^{\dagger}$ Correspondence to:

Amy Toporowski

Email: amy.toporowski@finddx.org

Tel: $+41(22) 7100590$

FIND, Campus Biotech, 9 Chemin des Mines - 1202 Geneva, Switzerland

Word count: 4045 


\section{ABSTRACT}

\section{Introduction:}

Testing is critical to controlling the COVID-19 pandemic. Antigen-detecting rapid diagnostic tests (Ag-RDTs) that can be used at the point of care have the potential to increase access to COVID-19 testing, particularly in settings with limited laboratory capacity. This systematic review synthesized literature on specific use cases and performance of Ag-RDTs for detecting SARSCoV-2, for the first comprehensive assessment of Ag-RDT use in real-world settings.

\section{Methods:}

We searched three databases (PubMed, EMBASE and medRxiv) up to 12 April 2021 for publications on Ag-RDT use for large-scale screening, irrespective of symptoms, and surveillance of COVID-19, excluding studies of only presumptive COVID-19 patients. We tabulated data on the study setting, populations, type of test, diagnostic performance and operational findings. We assessed risk of bias using QUADAS-2 and an adapted tool for prevalence studies.

\section{Results:}

From 4313 citations, 39 studies conducted in asymptomatic and symptomatic adults were included. Study sample sizes varied from 40 to $>5$ million. Of 39 studies, 37 (94.9\%) investigated lateral flow Ag-RDTs and two (5.1\%) investigated multiplex sandwich chemiluminescent enzyme immunoassay Ag-RDTs. Six categories of testing (screening/surveillance) initiatives were identified: mass screening $(n=13)$, targeted screening $(n=11)$, healthcare entry testing $(n=6)$, athome testing $(n=4)$, surveillance $(n=4)$ and prevalence survey $(n=1)$. Across studies, Ag-RDT sensitivity varied from $40 \%$ to $100 \%$. Ag-RDTs were noted as convenient, easy-to-use and low cost, with a rapid turnaround time and high user acceptability. Risk of bias was generally low or unclear across the studies.

\section{Conclusion:}

This systematic review demonstrates the use of Ag-RDTs across a wide range of real-world settings for screening and surveillance of COVID-19 in both symptomatic and asymptomatic individuals. Ag-RDTs were overall found to be easy-to-use, low cost and rapid tools, when consideration is given to their implementation and interpretation. The review was funded by FIND, the global alliance for diagnostics.

Keywords (3-10): SARS-CoV-2; COVID-19; rapid diagnostic test; antigen; testing; surveillance; use cases 


\section{SUMMARY}

What is already known?

- Antigen-detecting rapid diagnostic tests (Ag-RDTs) have the potential to substantially improve access to timely testing for COVID-19 and are being deployed in a variety of settings around the world

- While studies have investigated the diagnostic accuracy of Ag-RDTs, less is known about how and in what settings Ag-RDTs are being used around the world and their performance in these different settings

What are the new findings?

- $\quad$ Ag-RDTs are being used in a diverse range of real-world settings for mass screening and surveillance of COVID-19 among symptomatic and asymptomatic individuals

- The sensitivity of $\mathrm{Ag}$-RDTs is variable - ranging from $40 \%$ to $100 \%$ - and in some cases low compared with RT-PCR, meaning that the value of testing with Ag-RDTs needs to be carefully evaluated for each use case taking into account factors such as the prevalence of COVID-19 in the population, the consequences of false positive or false negative results, and whether confirmatory testing of positive or negative Ag-RDT results with RT-PCR is required

- Nevertheless, Ag-RDTs are generally reported as being easy to use and low cost, with a rapid turnaround time that enables timely identification of cases and subsequent interventions to prevent onward transmission of COVID-19

What do the new findings imply?

- The evidence indicates that Ag-RDTs can be effectively deployed across a broad range of settings when consideration is given to how they are implemented and interpreted

- The development of more detailed, evidence-based testing policies for Ag-RDTs will be important to help countries implement effective testing programmes and make the best use of $\mathrm{Ag}$-RDTs as part of the COVID-19 testing toolkit 


\section{INTRODUCTION}

Testing for SARS-CoV-2 remains a critical tool in controlling the COVID-19 pandemic. Testing allows the early identification of cases, enabling rapid isolation of positive cases and linkage to treatment, as well as monitoring of outbreaks and broader epidemiological surveillance. Antigen-detecting rapid diagnostic tests (Ag-RDTs) that can be used the point of care have the potential to expand timely access to COVID-19 testing, particularly in settings with limited laboratory capacity or in outbreak settings. As Ag-RDT results can be made available in 15-30 minutes, they have applications in a variety of settings including screening ahead of mass events, rapid testing at ports of entry, and for surveillance, particularly in settings without laboratory facilities for molecular tests.

Ag-RDTs are one of two main classes of diagnostic tools for detecting active SARS-CoV-2 infection, the other being nucleic acid amplification tests (NAATs) such as real time reversetranscription polymerase chain reaction (rRT-PCR)-based assays. ${ }^{12}$ Ag-RDTs work by detecting SARS-CoV-2 antigens produced by the replicating virus in respiratory secretions, while NAATs detect viral RNA. ${ }^{12}$ The accuracy of Ag-RDTs is dependent on factors such as the viral load in the specimen, the quality of the sample and time from onset of infection. ${ }^{2}$ While the sensitivity of Ag-RDTs is typically lower than NAATs, they have advantages in terms of their simplicity, low cost and rapid results compared with NAATs, which require laboratory facilities and trained technicians. ${ }^{12}$ Ag-RDTs are usually most accurate when viral loads are highest, shortly before and in the first week after symptom onset. ${ }^{23}$

A number of Ag-RDTs have received country regulatory approvals and are being deployed in a variety of settings for mass or targeted screening of specific groups like healthcare workers, schoolchildren and travellers. Guidance around the use of Ag-RDTs is varied. The World Health Organization (WHO) has issued interim guidance on the use of Ag-RDTs, recommending that Ag-RDTs meeting the minimum performance requirements of $\geq 80 \%$ sensitivity and $\geq 97 \%$ specificity compared with a NAAT reference assay can be used in settings likely to have the most impact on early detection of cases for care and contact tracing and where test results are most likely to be correct. Priority uses include community testing of symptomatic individuals meeting the suspected COVID-19 case definition, to detect and respond to suspected outbreaks of COVID-19, and to screen asymptomatic individuals at high risk of COVID-19, including health workers, contacts of cases and other at-risk individuals. However, information on country-level testing policies for Ag-RDTs collected by FIND, the global alliance for diagnostics, shows that such policies can vary substantially by country. ${ }^{4}$

While a number of studies have characterized the diagnostic accuracy of Ag-RDTs, ${ }^{3}$ 5-7 a comprehensive assessment of how Ag-RDTs are being used in the real world and their performance in each setting has not been conducted to date. In this systematic review, we aimed to synthesize the published and preprint literature regarding specific use cases and overall performance of Ag-RDTs for detection of SARS-CoV-2 in specific settings. Our primary objectives were to understand (i) settings where Ag-RDTs have been used for COVID-19 screening and/or surveillance, ii) and what were their performance characteristics across varied settings. 


\section{METHODS}

\section{Search strategy}

Three reviewers (AA, JB, EM) searched two electronic databases of published literature (PubMed, EMBASE) and one preprint database (medRxiv). The search string contained two elements: "COVID-19" and "antigen". Neither patient databases nor the grey literature were searched. No restrictions were applied on year of publication. The search was run three times, on 14 December 2020, 22 February 2021 and 12 April 2021. The protocol for this review was not registered.

\section{Inclusion criteria}

Studies published in English and French were included. Reference lists of screened full-text publications and reviews were reviewed to identify potential publications that were not found in the original search.

There were two types of use cases of interest in this review. The first was mass screening, irrespective of symptoms across a wide variety of settings, e.g. workplace, schools, universities, airports, essential workers; this included healthcare centres for patient admittance or triage, as well as healthcare workers and hospital staff, if testing was not based on clinical or epidemiological suspicion. The second was surveillance, which included two settings: i) serial or repeat testing of well-defined groups, e.g. students in professional medical training programmes, professional sports franchises (players and staff), and ii) random samples of a large population, all without clinical or epidemiological suspicion of SARS-CoV-2 infection.

Eligible populations included individuals of any age and from any geographic region who had undergone testing with a SARS-CoV-2 Ag-RDT as part of a screening strategy that was not limited exclusively to presumptive patients. Studies were both prospective or retrospective in nature and single- or multiple-gated in terms of enrollment. Studies were not required to utilize a reference test, such as RT-PCR, for inclusion.

\section{Exclusion criteria}

Studies where an Ag-RDT was not the index test of interest were excluded, as were modelling studies. Diagnostic accuracy studies (DAS) that did not use an Ag-RDT in the context of mass screening or surveillance were also excluded, for example, DAS looking solely at Ag-RDT performance at a testing site for people referred for COVID-19 testing by healthcare workers.

Studies with a population that consisted only of presumptive COVID-19 patients (e.g. those with symptoms indicative of COVID-19 who requiring testing as part of clinical diagnosis) were therefore also excluded, as this did not fit the criterion of mass screening or surveillance. In addition, case series and studies of Ag-RDTs in the preclinical or analytical validation stages were excluded.

\section{Screening, study selection, and data extraction}

All citations captured by the search were compiled, de-duplicated and managed in Covidence. ${ }^{8}$ All preprints and publications were screened for eligibility by two of three reviewers (AA, JB, EM) 
by title, abstract, and full-text. Disagreements were resolved through discussion between the same three reviewers. A structured Google form was piloted with a subset of studies and used for data extraction, with double data extraction of each study performed by four authors (AA, JB, EM, TU).

Information on the study setting, population, type of testing, brand of test, diagnostic performance and other outcomes were extracted, along with operational findings and author conclusions. A complete list of extracted fields is shown in Supplementary Table 1. Data entries for each study were reviewed and harmonized by four authors (AA, JB, EM, TU).

\section{Quality assessment}

For DAS, the revised Quality Assessment of Diagnostic Accuracy Studies (QUADAS-2) tool ${ }^{9}$ was adapted to fit the scope of the systematic review and used to assess risk of bias in each of four domains (patient selection, index test, reference standard, and flow and timing). For other studies reporting outcomes such as prevalence, test positivity and effectiveness, a tool based on the approach proposed by Munn et al. 2015 for assessing the quality of prevalence studies ${ }^{10}$ was developed to assess the risk of bias. Definitions for the questions included in each tool are provided in Supplementary Tables 2 and 3. Double quality assessment was performed for each study by two of three authors (AA, JB, TU), with discrepancies resolved through discussion between the same three authors.

\section{Main outcomes of interest and data synthesis}

Due to the heterogeneous nature of the inclusion criteria, several possible outcomes could have been reported by the included studies. These included diagnostic accuracy (sensitivity and specificity), test positivity rate, effectiveness (various definitions), impact (various definitions), and prevalence (various definitions). We also included operational findings that studies reported with respect to test utility, feasibility, and acceptability.

Findings were tabulated and summarized descriptively. Due to the heterogeneous nature of the studies and reporting of outcomes, no meta-analyses were performed. Outcomes are presented using the nomenclature of each study. Other assessments of Ag-RDT diagnostic accuracy exist and we invite readers to consult them regarding the performance of $\mathrm{Ag}$-RDT in various settings. ${ }^{3}$ $5-7$

\section{Patient and public involvement}

Patients and the public were not involved in this study.

\section{RESULTS}

After deduplication, 4313 studies from 2020 to 2021 were included (Figure 1). A total of 4147 studies were excluded after title/abstract screening and 165 full-text publications were assessed. Ultimately, 39 studies were included in our qualitative synthesis. Publications were most commonly excluded because they were DAS that did not use Ag-RDTs in the context of mass screening or surveillance, reviews or modelling studies (Figure 1). 
medRxiv preprint doi: https://doi.org/10.1101/2021.11.03.21265807; this version posted November 3, 2021. The copyright holder for this preprint (which was not certified by peer review) is the author/funder, who has granted medRxiv a license to display the preprint in perpetuity. It is made available under a CC-BY-NC-ND 4.0 International license .

Of the final subset of 39 studies, 35 were published and four were preprints at the time the review was conducted. A majority of studies were conducted in high-income countries, with 13/39 studies from the USA. Four of the 39 papers were conducted in low- and middle-income countries (LMICs), with three studies in India and one in Cameroon.

A single-gate design - where all participants were recruited according to a single set of criteria ${ }^{11}$ - was used in 35 of 39 studies; three studies utilized a phased intervention, and one study was two-gated. Different sampling strategies were employed in the studies, the most common being consecutive sampling (utilized in 12/39 studies). However, 18 studies did not describe their sampling scheme in a sufficiently clear manner to allow judgement.

\section{Quality assessment}

Quality assessments for the studies that reported various outcomes (diagnostic performance and others) are presented in Tables 1 and 2, respectively.

For diagnostic accuracy studies, two of the 22 studies were assessed as having a high risk of bias due to sampling, and 12 out of the 22 (54.5\%) studies had an unclear risk of bias due to sampling, as the specific sampling schemes used in the studies were not explicitly described in the paper (Table 1). Risk of bias was generally low across other aspects of the patient selection domain, and across the index test, reference standard, and flow and timing domains. All studies had low applicability concerns (Table 1).

For studies reporting on other outcomes, risk of bias was also generally low or unclear. Risk of bias was high for two studies in relation to the sampling scheme, as it was not adequately described in the respective articles. Risk of bias was unclear in $7 / 17$ studies (41.2\%) in relation to whether the condition was measured in a standard, reliable way for all participants, as it was not clear if the Ag-RDT had been performed using the same procedure for all participants.

\section{Results of individual studies}

Table 3 shows the results from individual studies. All studies but two investigated Ag-RDTs in the standalone strip format (lateral flow); two studies investigated the use of a multiplex test (sandwich chemiluminescent enzyme immunoassay). ${ }^{12}{ }^{13}$ The brand of test was reported for 36 of the 39 studies and two studies investigated the use of multiple brands of Ag-RDTs. ${ }^{14} 15$

\section{Type of testing}

Six broad types of screening initiatives were identified: mass screening, targeted screening, healthcare entry testing, at-home testing, surveillance and prevalence surveys. Figure 2 shows the range of study sizes across the different testing types.

Mass screening was used to describe non-targeted testing interventions such as broad community-based screening and population screening. Targeted screening was used to describe screening conducted in specific settings/venues, such as a small set of hospitals, schools, or airports. Testing administered in an individual's home was described as at-home testing, while 
testing before admission to/upon attendance at a hospital was described as healthcare entry testing. Studies to monitor COVID-19 in a defined setting or region were referred to as surveillance studies, while those looking at COVID-19 prevalence across a country were referred to as prevalence surveys.

The most common use of Ag-RDTs, in 13 studies, was for mass screening interventions, which included nationwide and citywide screening efforts, community hotspot testing and testing of travellers. Specific types of mass screening included two studies reporting multiple rounds of nationwide testing in Slovakia, where millions of individuals - over $80 \%$ of the age-eligible population - were tested using Ag-RDTs. ${ }^{15} 16$ Mass screening efforts also included three studies of drive-through testing in the USA and the Netherlands ${ }^{17-19}$, and three studies of community mass surge testing in the USA ${ }^{20-22}$ among others.

The second most common type of testing was targeted screening of specific populations, including testing at airports and ports of entry, ${ }^{12}{ }^{23}$ universities (campuses, dormitories, athletics programmes) ${ }^{24-27}$, and mixed interventions. ${ }^{132829}$

Six studies described testing interventions aimed at individuals seeking healthcare, including ahead of emergency room admittance, outpatient attendance, baby deliveries, and surgery. ${ }^{14} 30$ 34 Testing efforts specifically targeted at healthcare workers were described in five studies. ${ }^{14} 34-37$

Four studies described self-testing efforts that were carried out at-home; study populations included schoolteachers and hospital staff in two studies, and asymptomatic adult contacts of COVID-19 cases in the UK who were offered home tests in the other two studies. ${ }^{37-40}$ For hometesting studies, tests were given to participants with instructions for use and participants were asked to self-report their test results.

Four surveillance studies were conducted in Greece, Switzerland, USA, and the Netherlands, which used Ag-RDTs to monitor COVID-19 across an entire town, primary and secondary schoolchildren and teachers, university students and staff, and in professional football clubs, respectively. ${ }^{41-44}$

\section{Sample type}

Sample type was reported in all but six studies (Supplementary Table 4). Nasal or nasopharyngeal swabs were used in a vast majority of studies that reported sample type, either alone or in combination with another sample type (30/33 studies). One study investigated the use of buccal swabs in schoolchildren in Switzerland. ${ }^{43}$ Two studies investigated the use of saliva samples: the first as part of a mass screening effort in Austria, ${ }^{45}$ and the other for testing arrivals at three international airports in Japan. ${ }^{12}$

\section{Sensitivity of $\mathrm{Ag}-\mathrm{RDTS}$}

Across studies that reported diagnostic accuracy, sensitivity of Ag-RDTs varied:

a) Mass screening from $44.4 \%$ to $89.0 \%(n=9)$

b) Targeted screening from $40 \%$ to $100 \%(n=6)$ 
c) Healthcare entry testing from $54.2 \%$ to $80.3 \%(n=4)$

d) Surveillance from $85.7 \%$ to $~ 90 \%(n=2)$

e) In the single prevalence survey, sensitivity was $68.0 \%$ among symptomatic individuals and $46.9 \%$ among asymptomatic individuals

f) None of the studies of at-home testing provided estimates of sensitivity.

A trend for higher sensitivity among symptomatic versus asymptomatic individuals tested with Ag-RDTs was frequently observed, with lower sensitivity during early asymptomatic infections and in the later phase of infection.

Consequently, some studies recommended confirmatory testing with PCR when using Ag-RDTs. ${ }^{1253545}$ Studies where participants also underwent testing with PCR generally reported that Ag-RDTs performed better in individuals with relatively lower PCR cycle threshold values, indicating higher viral load, compared with groups in the same study with higher cycle threshold values. ${ }^{18} 1946$

Serial testing with Ag-RDTs was noted as a potential strategy to help compensate for limited sensitivity during early infection in some ${ }^{3746}$ but not all ${ }^{27}$ of the studies that investigated this approach.

\section{Operational findings}

Overall, Ag-RDTs were generally noted as easy to use and low cost, with a rapid turnaround time that enabled timely identification of cases and subsequent interventions to prevent onward transmission of COVID-19. Ag-RDTs were noted as a useful tool in large-scale screening of mixed populations (asymptomatic and symptomatic) and to screen asymptomatic individuals, particularly in high-prevalence settings, and in settings with limited resources.

In terms of the interpretation of the Ag-RDT result, various studies noted minimal user errors when the tests were conducted by trained personnel/healthcare workers or by participants themselves. However, studies emphasized the importance of training and clear instruction, with one study finding that field performance depended on the operator: the Ag-RDTs performed better in those with hands-on training than in those without. ${ }^{28}$

Another study identified that temperature/climate conditions can affect Ag-RDT performance, highlighting the importance of conducting Ag-RDTs in controlled conditions. ${ }^{18}$ Test-specific findings were also reported, including that "strong" positive bands tended to appear quickly ${ }^{17}$ and that optimal performance was achieved when scoring bands as positive on the lateral flow format Ag-RDTs when they extended across the full width of the strip, irrespective of intensity (rather than the manufacturer's recommendation to score any visible band as positive) ${ }^{21}$

The studies evaluating at-home testing interventions noted generally high acceptability and compliance with self-testing. ${ }^{37-40}$ Reports found that self-testing was usually performed to a 
satisfactory standard and that the majority of participants felt confident that they performed the test correctly. ${ }^{37-40}$ In one study of at-home testing among schoolteachers, participants reported that regular testing with Ag-RDTs was reassuring when working in schools during the pandemic. ${ }^{39}$ However, inequalities in the uptake of Ag-RDTs were identified, with lower uptake in deprived areas, ethnic minorities, areas with limited access to test sites and those with low digital access. ${ }^{47}$

\section{DISCUSSION}

The availability of SARS-CoV-2 Ag-RDTs has substantially broadened testing approaches for COVID-19, particularly in decentralized settings. This systematic review presents the first detailed assessment of Ag-RDTs use cases, in terms of how Ag-RDTs have been used for COVID-19 screening and surveillance since the start of the pandemic. Our findings demonstrate that Ag-RDTs are being used across a wide range of real-world settings, including as part of mass and targeted screening efforts, healthcare entry testing, at-home testing, surveillance and prevalence studies.

Overall, the studies included in this assessment have reported Ag-RDTs to be convenient, rapid, and low-cost interventions that can increase access to testing in a variety of settings to respond to changing testing needs. Importantly, the review identified that Ag-RDTs could be performed and interpreted correctly when conducted by healthcare workers, other trained personnel and by participants themselves across the different use cases.

The sensitivity of Ag-RDTs across studies in the review was variable compared with RT-PCR, and in some cases low, particularly among asymptomatic individuals. Sensitivity estimates ranged from $40 \%$ to $100 \%$ across the studies, which included either asymptomatic or mixed (asymptomatic and symptomatic) populations. Despite the lower sensitivity of Ag-RDTs compared with RT-PCR, a number of the studies noted the value of testing with Ag-RDTs, particularly in high-prevalence settings and where testing resources are limited, as a means to identify infected individuals that would otherwise be missed. However, certain studies did advise caution when using Ag-RDTs in situations where high test sensitivity is critical, for example in hospital emergency departments, particularly without confirmatory testing. ${ }^{33} 44$

The lower sensitivity of Ag-RDTs in asymptomatic individuals aligns with findings from meta-analyses of Ag-RDT diagnostic accuracy. In a Cochrane review, commercially available Ag-RDTs correctly identified SARS-CoV-2 infection in an average of $72 \%$ of people with symptoms, compared with $58 \%$ of people without symptoms. ${ }^{3}$ Another systematic review found similar results, with a pooled sensitivity of $76.7 \%$ in symptomatic patients versus $52.5 \%$ in asymptomatic patients. ${ }^{7}$

While this review demonstrates the diverse settings in which Ag-RDTs have been used, the variable performance of Ag-RDTs compared with RT-PCR means that the value of testing with this approach needs to be carefully evaluated for each use case. The prevalence of COVID-19 in a population is a particularly important consideration, as it affects the predictive value of the test; 
for example, the probability that a positive Ag-RDT result is a true positive is reduced in low prevalence settings. This has implications for what can be a delicate cost-benefit balance in terms of the societal benefits of the tests. Each false positive result in the real world may result in an entire classroom or a large part of workplace having to isolate at home for 10-14 days. In a healthcare setting, a high false positive rate may put undue pressure on health systems through the number of staff having to isolate. ${ }^{48}$ In contrast, false negative results may enable a SARS-CoV-2-infected person to get on an airplane or attend a mass event.

Nevertheless, it has been pointed out that these costs should be considered in terms of the broader picture, where without strategies to break chains of COVID-19 transmission on a smaller scale - in workplaces, in schools - governments have had to resort to lockdowns of entire cities and countries that have come at an enormous cost to individuals, societies and economies. ${ }^{49}$ Consequently, careful evaluation of each situation is needed to determine how Ag-RDTs can be optimally implemented to improve COVID-19 control. Important factors to consider include the prevalence of COVID-19 in the population, the consequences of false positive or false negative results, and how testing should be applied as part of testing algorithms (e.g. whether serial testing can mitigate low sensitivity, whether confirmatory testing of positive or negative Ag-RDT results with RT-PCR is required). WHO interim guidance notes that Ag-RDTs are most reliable in areas where there is ongoing community transmission of COVID-19 ( $25 \%$ test positivity rate) and advise the use of NAATs for first-line testing or confirmation of positive Ag-RDT results in low transmission settings. ${ }^{1}$

When considering the overall value of Ag-RDTs for large-scale screening and surveillance, consideration should also be given to whether the sensitivity of Ag-RDTs is of secondary importance to other characteristics such as turnaround time and accessibility. Indeed, a study modelling the effectiveness of repeated population screening for SARS-CoV-2 found that effective screening depended largely on the frequency and speed of testing and was only marginally improved by high test sensitivity. ${ }^{0}$ In addition, there is evidence from the USA that Ag-RDTs have a higher positive predictive value than RT-PCR for active SARS-CoV-2 infection, ${ }^{51}$ despite their generally lower overall sensitivity. This is important when evaluating the suitability of tests for widespread screening, where the priority is to quickly detect the most infectious individuals to prevent onwards transmission. In contrast, RT-PCR can detect viral RNA for prolonged periods beyond when live virus can be cultured - meaning that people can continue to test positive for SARS-CoV-2 by RT-PCR after they are no longer infectious. ${ }^{52}$

In terms of implications for testing policies, the results of this study demonstrate that there is demand for and use of Ag-RDTs as practical tools to detect SARS-CoV-2 across a broad range of settings and use cases. In particular, Ag-RDTs are being used for widespread screening of asymptomatic individuals beyond the scenarios outlined in interim global guidance from WHO. These findings align with the broader picture of COVID-19 testing emerging over the last year, which has seen calls for wider use of Ag-RDTs from public health experts ${ }^{49} 5253$ and the implementation of expansive programmes with Ag-RDTs in high-income countries like the UK and Canada for testing of the general population. ${ }^{53-55}$ 
It's clear that Ag-RDTs will have an important role to play in COVID-19 testing moving forward, but more detailed, evidence-based testing policies around the use of Ag-RDTs will be critical to help countries implement effective testing programmes for their settings. The findings from this work along with additional evidence generation, particularly in LMICs, can help inform more comprehensive and standardized policies.

Considering the systematic review as a whole, strengths include its comprehensive approach and inclusion of a broad range of studies from countries across Europe, North America, Africa and Asia. The review also included a number of studies with large sample sizes (21 of which had a sample size $>1000$ ). The systematic review was also conducted using rigorous methods, with study selection, data extraction and quality assessment performed and validated by multiple authors.

Some limitations of the approach are that the studies identified from the review are primarily from the USA and Europe, with fewer reports from LMICs. This limits understanding of how Ag-RDTs have been used across LMICs, but may also reflect that Ag-RDTs have been less available for widespread use in LMICs than in high-income countries.

Heterogeneity in study design and setting also prevented us from undertaking a meta-analysis and limits the extent to which individual study results can be compared. The search was also restricted to English and French, and did not include the grey literature, which may have excluded certain reports. Nevertheless, the review represents the first comprehensive assessment of how Ag-RDTs have been used in the real world.

\section{CONCLUSIONS}

This first detailed assessment of use cases for Ag-RDTs demonstrates their application across a wide range of real-world settings, including as part of mass and targeted screenings, healthcare entry testing, at-home testing, surveillance and prevalence studies. The approaches captured in this review highlight the versatility of Ag-RDTs as rapid, low cost, and easy to use COVID-19 screening tools for asymptomatic and symptomatic individuals. Although the sensitivity of Ag-RDTs can be low compared with RT-PCR, evidence indicates that Ag-RDTs can be easily deployed in a broad range of settings when consideration is given to how they are implemented and interpreted. The development of more detailed, evidence-based testing policies around the use of Ag-RDTs will be important to help countries implement effective testing programmes to help make the best use of Ag-RDTs as part of the COVID-19 testing toolkit. 


\section{REFERENCES}

1. World Health Organization. Antigen-detection in the diagnosis of SARS-CoV-2 infection. Interim guidance 6 October 2021, 2021.

2. World Health Organization. SARS-CoV-2 antigen-detecting rapid diagnostic tests: an implementation guide. Geneva: World Health Organization, 2020.

3. Dinnes J, Deeks JJ, Berhane S, et al. Rapid, point-of-care antigen and molecular-based tests for diagnosis of SARS-CoV-2 infection. Cochrane Database of Systematic Reviews 2021(3) doi: 10.1002/14651858.CD013705.pub2

4. FIND. COVID-19 DIAGNOSTICS POLICY MAPPING DASHBOARD 2021 [Available from: https://www.finddx.org/covid-19/policy-dashboard/ accessed 6 September 2021.

5. Heidelberg University Hospital. RAPID ANTIGEN TESTS FOR THE DIAGNOSIS OF A SARS-COV-2 INFECTION 2021 [Available from: https://www.klinikum.uniheidelberg.de/en/diagnostics-global-health accessed 4 August 2021.

6. FIND. FIND EVALUATION OF SARS-COV-2 ANTIGEN (AG) DETECTING TESTS 2021 [Available from: https://www.finddx.org/sarscov2-eval-antigen/ accessed 4 August 2021.

7. Brümmer LE, Katzenschlager S, Gaeddert M, et al. Accuracy of novel antigen rapid diagnostics for SARS-CoV-2: A living systematic review and meta-analysis. PLoS Med 2021;18(8):e1003735. doi: 10.1371/journal.pmed.1003735 [published Online First: 2021/08/13]

8. Veritas Health Innovation. Covidence Systematic Review Software. Melbourne, Australia 2018.

9. University of Bristol. QUADAS-2 2021 [Available from: https://www.bristol.ac.uk/populationhealth-sciences/projects/quadas/quadas-2/ accessed 4 August 2021.

10. Munn Z, Moola S, Lisy K, et al. Methodological guidance for systematic reviews of observational epidemiological studies reporting prevalence and cumulative incidence data. JBI Evidence Implementation 2015;13(3):147-53. doi: 10.1097/xeb.0000000000000054

11. Rutjes AW, Reitsma JB, Vandenbroucke JP, et al. Case-control and two-gate designs in diagnostic accuracy studies. Clin Chem 2005;51(8):1335-41. doi: 10.1373/clinchem.2005.048595 [published Online First: 2005/06/18]

12. Yokota I, Shane PY, Teshima T. Logistic advantage of two-step screening strategy for SARS-CoV-2 at airport quarantine. Travel Med Infect Dis 2021;43:102127. doi: 10.1016/j.tmaid.2021.102127 [published Online First: 2021/06/27]

13. Gili A, Paggi R, Russo C, et al. Evaluation of Lumipulse(R) G SARS-CoV-2 antigen assay automated test for detecting SARS-CoV-2 nucleocapsid protein (NP) in nasopharyngeal swabs for community and population screening. Int $J$ Infect Dis 2021;105:391-96. doi: 10.1016/j.jid.2021.02.098 [published Online First: 2021/03/02]

14. Regev-Yochay G, Kriger O, Beni S, et al. Real World Performance of SARS-CoV-2 Antigen Rapid Diagnostic Tests in Various Clinical Settings. medRxiv $2021: 2021.03 .02 .21252400$. doi: 10.1101/2021.03.02.21252400

15. Frnda J, Durica M. On Pilot Massive COVID-19 Testing by Antigen Tests in Europe. Case Study: Slovakia. Infect Dis Rep 2021;13(1):45-57. doi: 10.3390/idr13010007 [published Online First: 2021/01/13]

16. Pavelka M, Van-Zandvoort K, Abbott S, et al. The impact of population-wide rapid antigen testing on SARS-CoV-2 prevalence in Slovakia. Science 2021;372(6542):635-41. doi: 10.1126/science.abf9648

17. Igloi Z, Velzing J, van Beek J, et al. Clinical Evaluation of Roche SD Biosensor Rapid Antigen Test for SARS-CoV-2 in Municipal Health Service Testing Site, the Netherlands. 
medRxiv preprint doi: https://doi.org/10.1101/2021.11.03.21265807; this version posted November 3, 2021. The copyright holder for this preprint

(which was not certified by peer review) is the author/funder, who has granted medRxiv a license to display the preprint in perpetuity.

It is made available under a CC-BY-NC-ND 4.0 International license .

Emerg Infect Dis 2021;27(5):1323-29. doi: 10.3201/eid2705.204688 [published Online First: 2021/03/17]

18. Pollock NR, Jacobs JR, Tran K, et al. Performance and Implementation Evaluation of the Abbott BinaxNOW Rapid Antigen Test in a High-Throughput Drive-Through Community Testing Site in Massachusetts. J Clin Microbiol 2021;59(5) doi: 10.1128/JCM.00083-21 [published Online First: 2021/02/25]

19. Pollock NR, Tran K, Jacobs JR, et al. Performance and Operational Evaluation of the Access Bio CareStart Rapid Antigen Test in a High-Throughput Drive-Through Community Testing Site in Massachusetts. Open Forum Infect Dis 2021;8(7):ofab243. doi: 10.1093/ofid/ofab243 [published Online First: 2021/07/13]

20. Pilarowski G, Marquez C, Rubio L, et al. Field performance and public health response using the BinaxNOW TM Rapid SARS-CoV-2 antigen detection assay during community-based testing. Clin Infect Dis 2020 doi: 10.1093/cid/ciaa1890 [published Online First: 2020/12/29]

21. Pilarowski G, Lebel P, Sunshine S, et al. Performance Characteristics of a Rapid Severe Acute Respiratory Syndrome Coronavirus 2 Antigen Detection Assay at a Public Plaza Testing Site in San Francisco. J Infect Dis 2021;223(7):1139-44. doi: 10.1093/infdis/jiaa802 [published Online First: 2021/01/05]

22. Shah MM, Salvatore PP, Ford L, et al. Performance of Repeat BinaxNOW Severe Acute Respiratory Syndrome Coronavirus 2 Antigen Testing in a Community Setting, Wisconsin, November 2020-December 2020. Clin Infect Dis 2021;73(Suppl 1):S54-S57. doi: 10.1093/cid/ciab309 [published Online First: 2021/04/29]

23. Cerutti F, Burdino E, Milia MG, et al. Urgent need of rapid tests for SARS CoV-2 antigen detection: Evaluation of the SD-Biosensor antigen test for SARS-CoV-2. J Clin Virol 2020;132:104654. doi: 10.1016/j.jcv.2020.104654 [published Online First: 2020/10/15]

24. Okoye NC, Barker AP, Curtis K, et al. Performance Characteristics of BinaxNOW COVID-19 Antigen Card for Screening Asymptomatic Individuals in a University Setting. J Clin Microbiol 2021;59(4) doi: 10.1128/JCM.03282-20 [published Online First: 2021/01/30]

25. Pray IW, Ford L, Cole D, et al. Performance of an Antigen-Based Test for Asymptomatic and Symptomatic SARS-CoV-2 Testing at Two University Campuses - Wisconsin, September-October 2020. MMWR Morb Mortal Wkly Rep 2021;69(5152):1642-47. doi: 10.15585/mmwr.mm695152a3 [published Online First: 2021/01/01]

26. Betancourt WQ, Schmitz BW, Innes GK, et al. COVID-19 containment on a college campus via wastewater-based epidemiology, targeted clinical testing and an intervention. Sci Total Environ 2021;779:146408. doi: 10.1016/j.scitotenv.2021.146408 [published Online First: 2021/03/21]

27. Moreno GK, Braun KM, Pray IW, et al. Severe Acute Respiratory Syndrome Coronavirus 2 Transmission in Intercollegiate Athletics Not Fully Mitigated With Daily Antigen Testing. Clinical Infectious Diseases 2021;73(Supplement_1):S45-S53. doi: 10.1093/cid/ciab343

28. Peto T, Team UC-LFO. COVID-19: Rapid antigen detection for SARS-CoV-2 by lateral flow assay: A national systematic evaluation of sensitivity and specificity for mass-testing. EClinicalMedicine 2021;36:100924. doi: 10.1016/j.eclinm.2021.100924 [published Online First: 2021/06/09]

29. Boum Y, Fai KN, Nicolay B, et al. Performance and operational feasibility of antigen and antibody rapid diagnostic tests for COVID-19 in symptomatic and asymptomatic patients in Cameroon: a clinical, prospective, diagnostic accuracy study. Lancet Infect Dis 2021 doi: 10.1016/S1473-3099(21)00132-8 [published Online First: 2021/03/29]

30. Rottenstreich A, Zarbiv G, Kabiri D, et al. Rapid antigen detection testing for universal screening for severe acute respiratory syndrome coronavirus 2 in women admitted for delivery. Am J Obstet Gynecol 2021;224(5):539-40. doi: 10.1016/j.ajog.2021.01.002 [published Online First: 2021/01/17] 
medRxiv preprint doi: https://doi.org/10.1101/2021.11.03.21265807; this version posted November 3, 2021. The copyright holder for this preprint

(which was not certified by peer review) is the author/funder, who has granted medRxiv a license to display the preprint in perpetuity.

It is made available under a CC-BY-NC-ND 4.0 International license .

31. Tripathy D, Roy AK, Khanna RC, et al. Point-of-care rapid antigen testing for COVID-19 at a tertiary eye care facility: Role in commencement of elective surgeries, contact tracing and implementation of back-to-work policy. Indian J Ophthalmol 2021;69(4):964-70. doi: 10.4103/ijo.IJO_3119_20 [published Online First: 2021/03/18]

32. Turcato $G$, Zaboli $A$, Pfeifer N, et al. Clinical application of a rapid antigen test for the detection of SARS-CoV-2 infection in symptomatic and asymptomatic patients evaluated in the emergency department: A preliminary report. J Infect 2021;82(3):e14-e16. doi: 10.1016/j.jinf.2020.12.012 [published Online First: 2020/12/22]

33. Van Honacker E, Van Vaerenbergh K, Boel A, et al. Comparison of five SARS-CoV-2 rapid antigen detection tests in a hospital setting and performance of one antigen assay in routine practice: a useful tool to guide isolation precautions? J Hosp Infect 2021 doi: 10.1016/j.jhin.2021.03.021 [published Online First: 2021/04/01]

34. Dalal A, Sonika U, Kumar M, et al. COVID-19 Rapid Antigen Test: Role in Screening Prior to Gastrointestinal Endoscopy. Clin Endosc 2021 doi: 10.5946/ce.2020.295 [published Online First: 2021/03/05]

35. James AE, Gulley T, Kothari A, et al. Performance of the BinaxNOW coronavirus disease 2019 (COVID-19) Antigen Card test relative to the severe acute respiratory coronavirus virus 2 (SARS-CoV-2) real-time reverse transcriptase polymerase chain reaction (rRTPCR) assay among symptomatic and asymptomatic healthcare employees. Infect Control Hosp Epidemiol 2021:1-3. doi: 10.1017/ice.2021.20 [published Online First: 2021/01/26]

36. Herrera V, Hsu V, Adewale A, et al. Testing Healthcare Workers Exposed to COVID19 using Rapid Antigen Detection. medRxiv 2020:2020.08.12.20172726. doi: 10.1101/2020.08.12.20172726

37. Downs LO, Eyre DW, O'Donnell D, et al. Home-based SARS-CoV-2 lateral flow antigen testing in hospital workers. J Infect 2021;82(2):282-327. doi: 10.1016/j.jinf.2021.01.008 [published Online First: 2021/02/13]

38. Martin AF, Denford S, Love N, et al. Engagement with daily testing instead of self-isolating in contacts of confirmed cases of SARS-CoV-2. BMC Public Health 2021;21(1):1067. doi: 10.1186/s12889-021-11135-7

39. Hoehl S, Schenk B, Rudych O, et al. At-home self-testing of teachers with a SARS-CoV-2 rapid antigen test to reduce potential transmissions in schools. Results of the SAFE School Hesse Study 2020:2020.12.04.20243410. doi: 10.1101/2020.12.04.20243410

40. Love N, Ready D, Turner C, et al. The acceptability of testing contacts of confirmed COVID19 cases using serial, self-administered lateral flow devices as an alternative to selfisolation. medRxiv 2021:2021.03.23.21254168. doi: 10.1101/2021.03.23.21254168

41. Smith RL, Gibson LL, Martinez PP, et al. Longitudinal Assessment of Diagnostic Test Performance Over the Course of Acute SARS-CoV-2 Infection. The Journal of Infectious Diseases 2021 doi: 10.1093/infdis/jiab337

42. Kotsiou OS, Pantazopoulos I, Papagiannis D, et al. Repeated Antigen-Based Rapid Diagnostic Testing for Estimating the Coronavirus Disease 2019 Prevalence from the Perspective of the Workers' Vulnerability before and during the Lockdown. International Journal of Environmental Research and Public Health 2021;18(4):1638.

43. Kriemler S, Ulyte A, Ammann P, et al. Surveillance of Acute SARS-CoV-2 Infections in School Children and Point-Prevalence During a Time of High Community Transmission in Switzerland. Frontiers in Pediatrics 2021;9(159) doi: 10.3389/fped.2021.645577

44. Winkel B, Schram E, Gremmels H, et al. Screening for SARS-CoV-2 infection in asymptomatic individuals using the Panbio COVID-19 antigen rapid test (Abbott) compared with RT-PCR: a prospective cohort study. BMJ Open 2021;11(10):e048206. doi: 10.1136/bmjopen-2020-048206 
medRxiv preprint doi: https://doi.org/10.1101/2021.11.03.21265807; this version posted November 3, 2021. The copyright holder for this preprint

(which was not certified by peer review) is the author/funder, who has granted medRxiv a license to display the preprint in perpetuity.

It is made available under a CC-BY-NC-ND 4.0 International license .

45. Seitz $T$, Schindler $S$, Winkelmeyer $P$, et al. Evaluation of rapid antigen tests based on saliva for the detection of SARS-CoV-2. J Med Virol 2021;93(7):4161-62. doi:

10.1002/jmv.26983 [published Online First: 2021/04/01]

46. Sood N, Shetgiri R, Rodriguez A, et al. Evaluation of the Abbott BinaxNOW rapid antigen test for SARS-CoV-2 infection in children: Implications for screening in a school setting. PLoS One 2021;16(4):e0249710. doi: 10.1371/journal.pone.0249710 [published Online First: 2021/04/06]

47. Green MA, Garcia-Finana M, Barr B, et al. Evaluating social and spatial inequalities of large scale rapid lateral flow SARS-CoV-2 antigen testing in COVID-19 management: An observational study of Liverpool, UK (November 2020 to January 2021). Lancet Reg Health Eur 2021;6:100107. doi: 10.1016/j.lanepe.2021.100107 [published Online First: 2021/05/19]

48. Kanji JN, Proctor DT, Stokes W, et al. Multicenter Postimplementation Assessment of the Positive Predictive Value of SARS-CoV-2 Antigen-Based Point-of-Care Tests Used for Screening of Asymptomatic Continuing Care Staff. J Clin Microbiol 2021;59(11):e0141121. doi: 10.1128/jcm.01411-21 [published Online First: 2021/07/22]

49. Fearon E, Buchan IE, Das R, et al. SARS-CoV-2 antigen testing: weighing the false positives against the costs of failing to control transmission. Lancet Respir Med 2021;9(7):685-87. doi: 10.1016/s2213-2600(21)00234-4 [published Online First: 2021/06/18]

50. Larremore DB, Wilder B, Lester $\mathrm{E}$, et al. Test sensitivity is secondary to frequency and turnaround time for COVID-19 screening. Sci Adv 2021;7(1) doi: 10.1126/sciadv.abd5393 [published Online First: 2020/11/22]

51. Pekosz A, Parvu V, Li M, et al. Antigen-Based Testing but Not Real-Time Polymerase Chain Reaction Correlates With Severe Acute Respiratory Syndrome Coronavirus 2 Viral Culture. Clinical Infectious Diseases 2021 doi: 10.1093/cid/ciaa1706

52. Mina MJ, Peto TE, García-Fiñana M, et al. Clarifying the evidence on SARS-CoV-2 antigen rapid tests in public health responses to COVID-19. Lancet 2021;397(10283):1425-27. doi: 10.1016/s0140-6736(21)00425-6 [published Online First: 2021/02/21]

53. Mina MJ, Phillips, S. Rapid Tests Are the Answer to Living With Covid-19. The New York Times.

54. Medicines \& Healthcare products Regulatory Agency. For patients, the public and professional users: a guide to COVID-19 tests and testing kits 2021 [Available from: https://www.gov.uk/government/publications/how-tests-and-testing-kits-for-coronaviruscovid-19-work/for-patients-the-public-and-professional-users-a-guide-to-covid-19-testsand-testing-kits accessed 6 September 2021.

55. Government of Canada. Government of Canada makes rapid antigen tests available to more small and medium-sized organizations through new pharmacy partners 2021 [Available from: https://www.canada.ca/en/health-canada/news/2021/08/government-ofcanada-makes-rapid-antigen-tests-available-to-more-small-and-medium-sizedorganizations-through-new-pharmacy-partners.html accessed 6 September 2021.

56. Alemany A, Baro B, Ouchi D, et al. Analytical and clinical performance of the panbio COVID19 antigen-detecting rapid diagnostic test. J Infect 2021;82(5):186-230. doi: 10.1016/j.jinf.2020.12.033 [published Online First: 2021/01/10]

57. Colavita F, Vairo F, Meschi S, et al. COVID-19 Rapid Antigen Test as Screening Strategy at Points of Entry: Experience in Lazio Region, Central Italy, August-October 2020. Biomolecules 2021;11(3) doi: 10.3390/biom11030425 [published Online First: 2021/04/04]

58. Babu GR, Sundaresan R, Athreya S, et al. The burden of active infection and anti-SARSCoV-2 IgG antibodies in the general population: Results from a statewide sentinel-based population survey in Karnataka, India. International journal of infectious diseases : IJID : 
medRxiv preprint doi: https://doi.org/10.1101/2021.11.03.21265807; this version posted November 3, 2021. The copyright holder for this preprint (which was not certified by peer review) is the author/funder, who has granted medRxiv a license to display the preprint in perpetuity.

\begin{abstract}
It is made available under a CC-BY-NC-ND 4.0 International license.
\end{abstract}
official publication of the International Society for Infectious Diseases 2021;108:27-36. doi: 10.1016/j.jijid.2021.05.043 


\section{DECLARATIONS}

\section{Availability of data and materials}

The datasets used and/or analysed during the current study are available from the corresponding author on reasonable request.

\section{Contributors}

The study was conceived by AA, JB, SGS, EM, and AT. The systematic review was performed by $A A, J B, E M$, and TU as detailed in the methods section. The manuscript drafts were developed by $A A, E M, J B$, and TU with input from the other authors. All authors contributed to interpretation of data and editing of the article and approved the final version of the manuscript.

\section{Funding}

Funding for the study was provided by FIND; however, ultimate responsibility for opinions and conclusions in the article lies with the authors.

\section{Competing interests}

AT and SC are employed by FIND and SGS was employed by FIND at the time of the study. TU is a consultant for FIND. AA and NPP report a grant from the Canadian Institutes of Health Research for a project on COVID-19 testing unrelated to this study and copyright for a digital program for COVID-19 self-testing. FIND is a not-for-profit foundation that supports the evaluation of publicly prioritized tuberculosis assays and the implementation of WHO-approved (guidance and prequalification) assays using donor grants. FIND has product evaluation agreements with several private sector companies that design diagnostics for tuberculosis and other diseases. These agreements strictly define FIND's independence and neutrality with regard to these private sector companies. 
Table 1. Quality assessment for diagnostic accuracy studies using modified QUADAS-2

\begin{tabular}{|c|c|c|c|c|c|c|c|c|c|c|}
\hline \multirow[b]{2}{*}{$\begin{array}{l}\text { Study (First } \\
\text { author) }\end{array}$} & \multicolumn{8}{|c|}{ Risk of bias } & \multicolumn{2}{|c|}{ Applicability } \\
\hline & 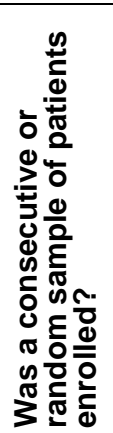 & 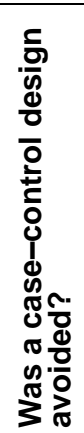 & 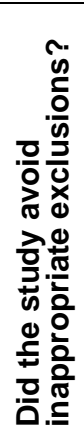 & 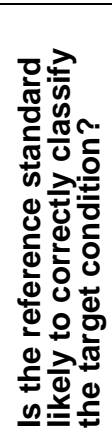 & 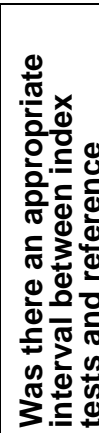 & 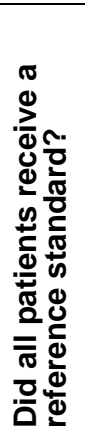 & 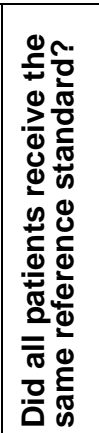 & 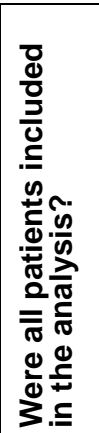 & 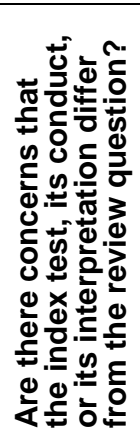 & 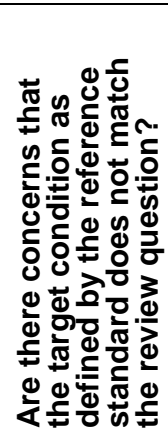 \\
\hline Alemany $^{56}$ & ? & + & $?$ & + & $?$ & + & + & + & + & + \\
\hline Turcato $^{32}$ & + & + & + & + & + & + & + & + & + & + \\
\hline Igloi ${ }^{17}$ & + & + & + & + & + & + & + & + & + & + \\
\hline Van Honacker ${ }^{33}$ & + & + & + & + & + & + & + & + & + & + \\
\hline Gili $^{13}$ & $?$ & + & + & + & + & + & + & + & + & + \\
\hline Seitz $^{45}$ & $?$ & + & $?$ & + & + & + & + & - & + & + \\
\hline Sood $^{46}$ & $?$ & + & + & + & + & + & + & + & + & + \\
\hline Pilarowski $^{20}$ & $?$ & + & $?$ & + & + & + & + & + & + & + \\
\hline Smith $^{41}$ & $?$ & - & + & + & + & + & + & - & + & + \\
\hline Pollock $^{18}$ & + & + & + & + & + & + & + & + & + & + \\
\hline Pollock $^{19}$ & + & + & + & + & + & + & + & + & + & + \\
\hline Boum $^{29}$ & + & + & + & + & $?$ & + & + & + & + & + \\
\hline Pilarowski ${ }^{21}$ & - & + & + & + & + & + & + & + & + & + \\
\hline Okoye $^{24}$ & $?$ & + & + & + & + & + & + & + & + & + \\
\hline Pray $^{25}$ & $?$ & + & + & + & + & + & + & + & + & + \\
\hline Shah $^{22}$ & ? & + & + & + & + & + & + & + & + & + \\
\hline James $^{35}$ & + & + & + & + & + & + & + & + & + & + \\
\hline Rottenstreich ${ }^{30}$ & + & + & + & + & + & + & + & + & + & + \\
\hline Regev-Yochay ${ }^{14}$ & $?$ & + & + & + & + & + & + & + & + & + \\
\hline Winkel $^{44}$ & ? & + & + & + & $?$ & - & + & + & + & + \\
\hline Kriemler $^{43}$ & - & + & - & + & + & + & + & + & + & + \\
\hline Cerutti $^{23}$ & $?$ & + & ? & + & + & + & + & + & + & + \\
\hline
\end{tabular}


medRxiv preprint doi: https://doi.org/10.1101/2021.11.03.21265807; this version posted November 3, 2021. The copyright holder for this preprint (which was not certified by peer review) is the author/funder, who has granted medRxiv a license to display the preprint in perpetuity.

It is made available under a CC-BY-NC-ND 4.0 International license .

Table 2. Quality assessment for non-diagnostic accuracy studies adapted from Munn et al.

\begin{tabular}{|c|c|c|c|c|c|c|}
\hline \multicolumn{7}{|c|}{ MUNN QA ASSESSMENT } \\
\hline $\begin{array}{l}\text { Study (first } \\
\text { author) }\end{array}$ & 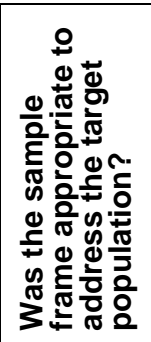 & 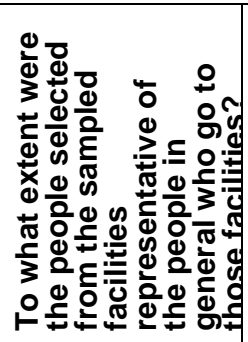 & 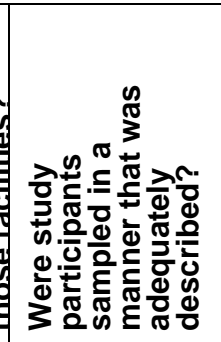 & 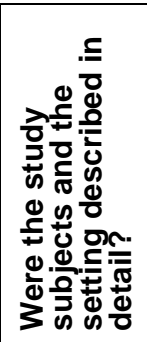 & 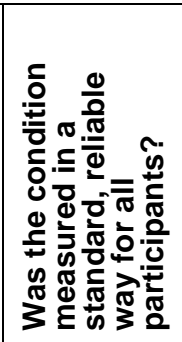 & 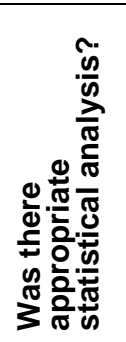 \\
\hline Dalal $^{34}$ & + & + & + & + & $?$ & N/A \\
\hline Peto $^{28}$ & $?$ & $?$ & $?$ & + & + & + \\
\hline Green $^{47}$ & + & $?$ & - & + & $?$ & + \\
\hline Hoeh $^{39}$ & + & + & - & + & + & N/A \\
\hline Betancourt $^{26}$ & + & + & + & + & $?$ & N/A \\
\hline Colavita $^{57}$ & + & + & $?$ & + & + & N/A \\
\hline Martin $^{38}$ & $?$ & $?$ & ? & + & + & + \\
\hline Downs $^{37}$ & + & + & $?$ & + & + & + \\
\hline Yokota $^{12}$ & + & + & + & + & + & + \\
\hline Frnda $^{15}$ & + & + & + & + & + & + \\
\hline Tripathy $^{31}$ & + & + & + & + & + & N/A \\
\hline Kotsiou ${ }^{42}$ & + & + & + & + & + & + \\
\hline Moreno $^{27}$ & + & + & + & + & + & N/A \\
\hline Herrera $^{36}$ & + & + & + & $?$ & $?$ & N/A \\
\hline Love $^{40}$ & + & + & + & + & ? & + \\
\hline Babu $^{58}$ & + & $?$ & $?$ & + & $?$ & + \\
\hline Pavelka $^{16}$ & + & + & + & + & $?$ & N/A \\
\hline
\end{tabular}


Table 3. Individual study results: Ag-RDT use cases, performance and operational findings

\begin{tabular}{|c|c|c|c|c|c|c|}
\hline $\begin{array}{l}\text { First author, } \\
\text { reference }\end{array}$ & Country & Study details & Brand/test name & $\begin{array}{l}\text { Sensitivity } \\
\text { (95\% CI) }\end{array}$ & $\begin{array}{l}\text { Specificity } \\
\text { (95\% Cl) }\end{array}$ & Other outcomes and operational findings \\
\hline \multicolumn{7}{|c|}{ Mass screening } \\
\hline Iglói ${ }^{17}$ & $\begin{array}{l}\text { The } \\
\text { Netherlands }\end{array}$ & $\begin{array}{l}\text { Drive-through testing site in } \\
\text { Rotterdam for adults, sx or } \\
\text { close contact of case }\end{array}$ & $\begin{array}{l}\text { SD Biosensor } \\
\text { SARS-CoV-2 Rapid } \\
\text { Antigen Test }\end{array}$ & $\begin{array}{l}84.9 \\
(79.1-89.4)\end{array}$ & $\begin{array}{l}99.5 \\
(98.7-99.8)\end{array}$ & $\begin{array}{l}95 \% \text { of strong positive samples appeared in }<5 \\
\text { minutes. }\end{array}$ \\
\hline Pilarowski ${ }^{21}$ & USA & $\begin{array}{l}\text { Community mass surge } \\
\text { testing campaign in San } \\
\text { Francisco for sx or asx } \\
\text { adults }\end{array}$ & $\begin{array}{l}\text { Abbott BinaxNOW } \\
\text { COVID-19 Ag Card }\end{array}$ & $\begin{array}{l}57.7 \\
(36.9-76.6)\end{array}$ & $\begin{array}{l}100 \\
(99.6-100)\end{array}$ & $\begin{array}{l}\text { The manufacturer's suggestion to score any } \\
\text { visible bands as positive led to excessive false- } \\
\text { positives; optimal performance was when bands } \\
\text { were scored as positive if they extended across } \\
\text { the full width of the strip, irrespective of intensity. }\end{array}$ \\
\hline Pollock $^{18}$ & USA & $\begin{array}{l}\text { Drive-through community } \\
\text { testing site outside a } \\
\text { hospital in Massachusetts } \\
\text { for sx or asx children and } \\
\text { adults }\end{array}$ & $\begin{array}{l}\text { Abbott BinaxNOW } \\
\text { COVID-19 Ag Card }\end{array}$ & $\begin{array}{l}\text { Asx adults: } \\
70.2 \\
(56.6-81.6) \\
\text { Asx } \\
\text { children: } \\
65.4 \\
(55.6-74.4)\end{array}$ & $\begin{array}{l}\text { Asx adults: } \\
99.6 \\
\text { (98.9-99.9) } \\
\text { Asx } \\
\text { children: } \\
99.0 \text { (98.0- } \\
99.6)\end{array}$ & $\begin{array}{l}\text { In } 30 \text { specimens run at temperatures below } \\
\text { manufacturer's recommendations, sensitivity } \\
\text { was } 66.7 \% \text { and specificity was } 95.2 \% \text {. Excellent } \\
\text { inter-operator agreement. Skilled lab staff can } \\
\text { perform and read } 20 \text { tests per hour. }\end{array}$ \\
\hline Sood $^{46}$ & USA & $\begin{array}{l}\text { Walk-up testing site in Los } \\
\text { Angeles County for sx or } \\
\text { asx children }\end{array}$ & $\begin{array}{l}\text { Abbott BinaxNOW } \\
\text { COVID-19 Ag Card }\end{array}$ & $\begin{array}{l}56.2 \\
(49.5-62.8)\end{array}$ & NA & $\begin{array}{l}\text { Positive concordance was higher among children } \\
\text { with lower Ct values on the RT-PCR test, } \\
\text { including in asymptomatic children. }\end{array}$ \\
\hline Pilarowski²0 & USA & $\begin{array}{l}\text { Community mass surge } \\
\text { testing campaign in San } \\
\text { Francisco for sx or asx } \\
\text { children and adults }\end{array}$ & $\begin{array}{l}\text { Abbott BinaxNOW } \\
\text { COVID-19 Ag Card }\end{array}$ & $\begin{array}{l}89.0 \\
(84.3-92.7)\end{array}$ & $\begin{array}{l}99.9 \\
(99.7-100)\end{array}$ & $\begin{array}{l}\text { With } 3 \text { tents and } 13 \text { total staff, } 100 \text { persons } \\
\text { tested/hour. For those with positive RAT, median } \\
\text { time from onsite registration to electronic results } \\
\text { notification was } 62 \text { min. }\end{array}$ \\
\hline Shah $^{22}$ & USA & $\begin{array}{l}\text { Community mass surge } \\
\text { testing campaign in } \\
\text { Wisconsin for sx and asx } \\
\text { children and adults }\end{array}$ & $\begin{array}{l}\text { Abbott BinaxNOW } \\
\text { COVID-19 Ag Card }\end{array}$ & $\begin{array}{l}77.2 \\
(72.4-81.6)\end{array}$ & $\begin{array}{l}99.6 \\
(99.2-99.8)\end{array}$ & $\begin{array}{l}\text { Minimal user error and high concordance } \\
(98.9 \%) \text { when test repeated at the same } \\
\text { encounter. }\end{array}$ \\
\hline Pollock ${ }^{19}$ & USA & $\begin{array}{l}\text { Drive-through community } \\
\text { testing site outside a }\end{array}$ & $\begin{array}{l}\text { Access Bio } \\
\text { CareStart COVID- } \\
19 \text { antigen }\end{array}$ & $\begin{array}{l}50 \\
(41.0-59.0)\end{array}$ & $\begin{array}{l}99.1 \\
(98.3-99.6)\end{array}$ & $\begin{array}{l}\text { Excellent inter-operator agreement, but } \\
\text { additional training of personnel warranted to }\end{array}$ \\
\hline
\end{tabular}




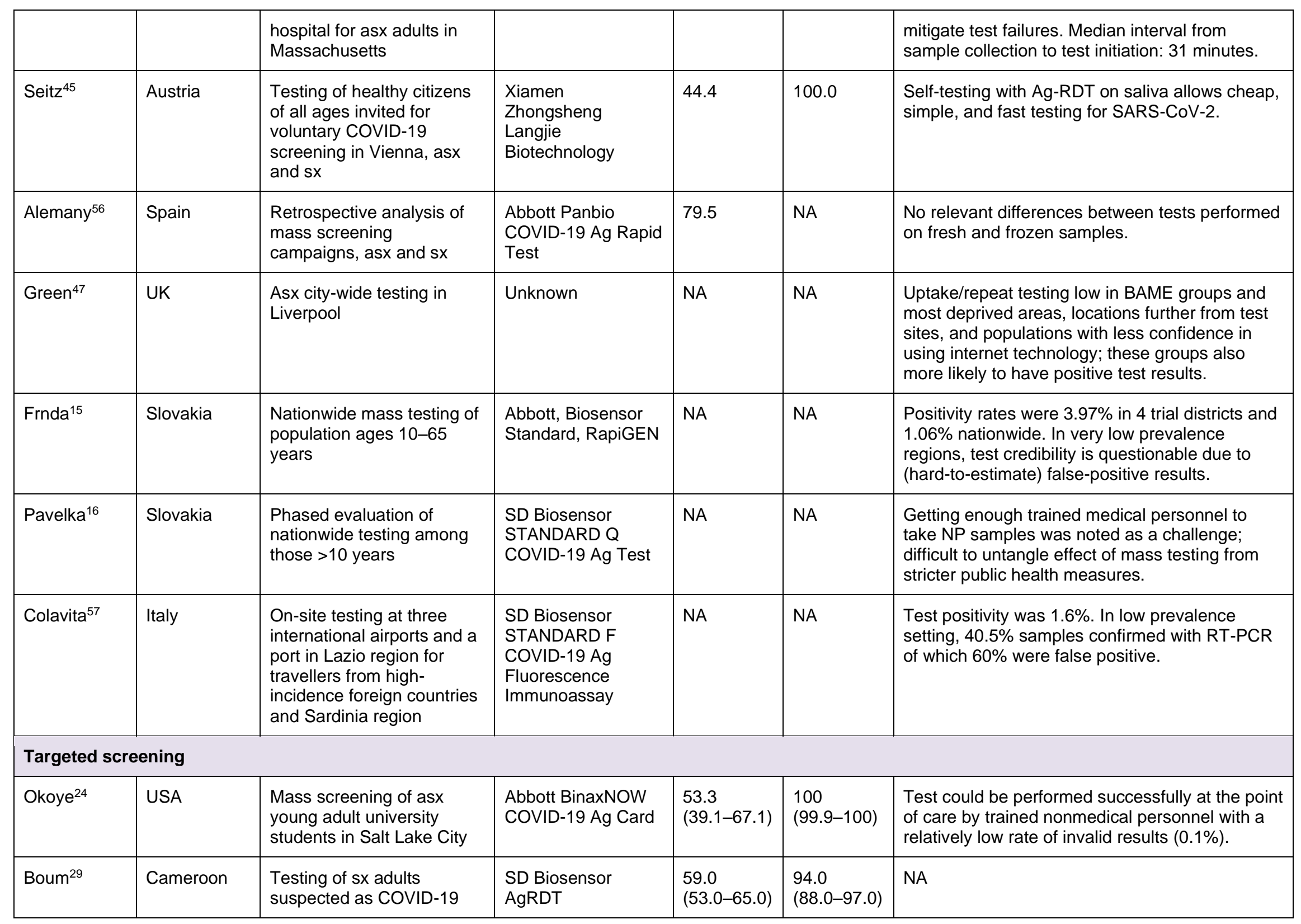




\begin{tabular}{|c|c|c|c|c|c|c|}
\hline & & $\begin{array}{l}\text { cases or already on } \\
\text { treatment and asx adults } \\
\text { presenting for voluntary } \\
\text { screening or referred } \\
\text { through contact tracing in } 8 \\
\text { sites in Yaoundé }\end{array}$ & & & & \\
\hline James $^{35}$ & USA & $\begin{array}{l}\text { Mandatory screening of all } \\
\text { patient-facing HCWs in an } \\
\text { acute care hospital in } \\
\text { Arkansas; } 95 \% \text { asx }\end{array}$ & $\begin{array}{l}\text { Abbott BinaxNOW } \\
\text { COVID-19 Ag Card }\end{array}$ & $\begin{array}{l}56.6 \\
(48.7-64.5)\end{array}$ & $\begin{array}{l}99.9 \\
(99.7-100)\end{array}$ & $\begin{array}{l}\text { Sensitivity was higher (83.3\%) in symptomatic } \\
\text { than asymptomatic people (51.6\%). }\end{array}$ \\
\hline Yokota $^{12}$ & Japan & $\begin{array}{l}\text { Testing of all arrivals at } \\
\text { three international airports; } \\
\text { those with "indeterminate" } \\
\text { Ag-RDT results (within } \\
\text { positive and negative } \\
\text { thresholds of } 4.0 \mathrm{pg} / \mathrm{mL} \\
\text { and } 0.67 \mathrm{pg} / \mathrm{mL} \text { ) had } \\
\text { additional molecular testing }\end{array}$ & $\begin{array}{l}\text { Fujirebio Lumipulse } \\
\text { SARS-CoV-2 Ag** }\end{array}$ & NA & NA & $\begin{array}{l}\text { Positivity rate was } 0.29 \% .513 \text { results were } \\
\text { within the indeterminate threshold, of which } 34 \\
\text { were confirmed positive. The two-step strategy } \\
\text { led to a } 95 \% \text { reduction in molecular test use } \\
\text { compared with universal deployment, saving } \\
\text { time and resources. }\end{array}$ \\
\hline Gili13 & Italy & $\begin{array}{l}\text { Unselected cohort of } \\
\text { swabs collected in schools, } \\
\text { prisons, elderly care } \\
\text { homes, and from hospital } \\
\text { HCW surveillance } \\
\text { programmes in Umbria }\end{array}$ & $\begin{array}{l}\text { Fujirebio Lumipulse } \\
\text { SARS-CoV-2 Ag** }\end{array}$ & 100 & 92.1 & $\begin{array}{l}\text { Tests were run on a multiplex reader, so process } \\
\text { was completely automated. Up to } 120 \\
\text { samples/hour may be run. }\end{array}$ \\
\hline Pray 25 & USA & $\begin{array}{l}\text { Testing of asx or sx } \\
\text { students and staff at two } \\
\text { Wisconsin universities }\end{array}$ & $\begin{array}{l}\text { Quidel Sofia SARS } \\
\text { Antigen Fluorescent } \\
\text { Immunoassay (FIA) }\end{array}$ & $\begin{array}{l}41.2 \\
(18.4-67.1)\end{array}$ & $\begin{array}{l}98.4 \\
(97.3-99.1)\end{array}$ & $\begin{array}{l}\text { All false-negative results from symptomatic } \\
\text { participants were from specimens collected }<5 \\
\text { days after onset of symptoms (median } 2 \text { days). }\end{array}$ \\
\hline Betancourt ${ }^{26}$ & USA & $\begin{array}{l}\text { Pre-screening of } \\
\text { wastewater with RT-PCR } \\
\text { at Arizona university dorm; } \\
\text { if positive, entire dorm } \\
\text { tested with Ag-RDT, plus } \\
\text { testing of sx students }\end{array}$ & $\begin{array}{l}\text { Quidel Sofia SARS } \\
\text { Antigen Fluorescent } \\
\text { Immunoassay }\end{array}$ & NA & NA & $\begin{array}{l}\text { Ag-RDT showed } 50 \% \text { effectiveness: identified } 1 \\
\text { person who was also RT-PCR+, missed } 1 \\
\text { person who was RT-PCR indeterminate (later } \\
\text { positive); wastewater surveillance + targeted } \\
\text { testing seems effective and acceptable. }\end{array}$ \\
\hline Moreno ${ }^{27}$ & USA & $\begin{array}{l}\text { Daily testing of asx } \\
\text { students and staff affiliated } \\
\text { with two university athletics } \\
\text { programmes }\end{array}$ & $\begin{array}{l}\text { Quidel Sofia SARS } \\
\text { Antigen Fluorescent } \\
\text { Immunoassay }\end{array}$ & NA & NA & $\begin{array}{l}\text { Antigen testing on the competition dates failed to } \\
\text { identify the index case, who may have been } \\
\text { infectious and exposed other athletes. }\end{array}$ \\
\hline
\end{tabular}




\begin{tabular}{|c|c|c|c|c|c|c|}
\hline Herrera ${ }^{\star 36}$ & USA & $\begin{array}{l}\text { Testing of HCWs at } \\
\text { ambulatory centres } \\
\text { exposed to COVID-19, asx } \\
\text { or sx }\end{array}$ & Unknown & NA & NA & $\begin{array}{l}\text { Test positivity: } \mathrm{sX}=11 \% \text {, asymptomatics }=2 \% \text {. } \\
\text { No asx Ag-RDT-negative HCW developed } \\
\text { symptoms or had evidence of transmitting } \\
\text { SARS-CoV- } 2 \text {. Due to low RT-PCR positivity rate, } \\
\text { samples were pooled to further conserve PCR } \\
\text { capacity. }\end{array}$ \\
\hline Cerutti23 & Italy & $\begin{array}{l}\text { Testing of travellers } \\
\text { returning home from } \\
\text { European high-risk } \\
\text { countries }\end{array}$ & $\begin{array}{l}\text { SD Biosensor } \\
\text { STANDARD Q } \\
\text { COVID-19 Ag Test }\end{array}$ & 40 & 100 & NA \\
\hline Peto 28 & UK & $\begin{array}{l}\text { Nationwide phased } \\
\text { evaluations of Ag-RDTs: } \\
\text { retrospective analysis of } \\
\text { patient samples from a } \\
\text { secondary healthcare } \\
\text { setting; drive-through } \\
\text { community testing; } \\
\text { community field } \\
\text { evaluations (secondary } \\
\text { healthcare (hospital) } \\
\text { setting, armed forces, } \\
\text { Public Health England } \\
\text { staff, school children; } \\
\text { regional COVID-19 testing } \\
\text { centres) }\end{array}$ & $\begin{array}{l}\text { Innova SARS-CoV- } \\
2 \text { Antigen Rapid } \\
\text { Qualitative Test }\end{array}$ & NA & 99.68 & $\begin{array}{l}\text { Poor transfer of the liquid within the device from } \\
\text { the reservoir onto the test strip was the most } \\
\text { common reason for kit failure. In field testing, } \\
\text { performance was dependent on the test } \\
\text { operator; those who had read a protocol } \\
\text { immediately prior to self-sampling did not } \\
\text { perform as well as individuals with hands-on } \\
\text { training. }\end{array}$ \\
\hline \multicolumn{7}{|c|}{ Healthcare entry testing } \\
\hline $\begin{array}{l}\text { Regev- } \\
\text { Yochay }{ }^{* 14}\end{array}$ & Israel & $\begin{array}{l}\text { Screening of asx patients } \\
\text { upon hospitalization and a } \\
\text { cohort of HCWs following } \\
\text { SARS-CoV-2 exposure }\end{array}$ & $\begin{array}{l}\text { Nowcheck COVID- } \\
19 \text { Ag test } \\
\text { (Bionote), Panbio } \\
\text { COVID-19 Ag rapid } \\
\text { test, (Abbott), BD } \\
\text { Veritor (BD), } \\
\text { GenBody COVID- } \\
19 \text { Ag (GenBody), } \\
\text { STANDARD Q } \\
\text { COVID-19 (SD- } \\
\text { Biosensor) }\end{array}$ & 65.9 & 99.8 & NA \\
\hline
\end{tabular}




\begin{tabular}{|c|c|c|c|c|c|c|}
\hline $\begin{array}{l}\text { Rottensreich } \\
30\end{array}$ & Israel & $\begin{array}{l}\text { Testing of asx pregnant } \\
\text { women admitted for } \\
\text { delivery in a university- } \\
\text { affiliated hospital }\end{array}$ & $\begin{array}{l}\text { Bionote NowCheck } \\
\text { COVID-19 Ag Test }\end{array}$ & $\begin{array}{l}55.6 \\
(21.2-86.3)\end{array}$ & $\begin{array}{l}100 \\
(99.7-100)\end{array}$ & NA \\
\hline Tripathy ${ }^{31}$ & India & $\begin{array}{l}\text { Testing of asx patients } \\
\text { undergoing elective } \\
\text { ophthalmic surgeries and } \\
\text { staff exposed to or with } \\
\text { presumptive COVID-19 in a } \\
\text { tertiary eye hospital }\end{array}$ & $\begin{array}{l}\text { SD Biosensor } \\
\text { STANDARD Q } \\
\text { COVID-19 Ag Test }\end{array}$ & NA & NA & $\begin{array}{l}\text { Mandatory Ag-RDT testing appeared to increase } \\
\text { surgery patients' feeling of safety around seeking } \\
\text { medical care during the pandemic. }\end{array}$ \\
\hline Turcato $^{32}$ & Italy & $\begin{array}{l}\text { Screening of all patients } \\
\text { presenting at the hospital } \\
\text { emergency department, } \\
\text { asx or sx }\end{array}$ & $\begin{array}{l}\text { SD Biosensor } \\
\text { Standard Q COVID- } \\
19 \text { Ag Test }\end{array}$ & $\begin{array}{l}80.3(74.9- \\
85.4)\end{array}$ & $\begin{array}{l}99.1(98.6- \\
99.3)\end{array}$ & $\begin{array}{l}\text { Use of Ag-RDTs in the emergency department } \\
\text { for screening of symptomatic and asymptomatic } \\
\text { patients can improve overall management of the } \\
\text { infectious risk, with a net clinical benefit. }\end{array}$ \\
\hline $\begin{array}{l}\text { Van } \\
\text { Honacker }{ }^{33}\end{array}$ & Belgium & $\begin{array}{l}\text { Screening of all hospital } \\
\text { emergency department } \\
\text { patients }\end{array}$ & $\begin{array}{l}\text { SD Biosensor } \\
\text { SARS-CoV-2 Rapid } \\
\text { Antigen Test }\end{array}$ & 54.2 & 99.7 & $\begin{array}{l}\text { Incorrect reading of test cassette caused false } \\
\text { positive in } 3 \text { out of } 12 \text { results. }\end{array}$ \\
\hline Dalal $^{34}$ & India & $\begin{array}{l}\text { Testing of exposed or sx } \\
\text { HCWs and all patients in } \\
\text { hospital outpatient } \\
\text { department before } \\
\text { gastrointestinal endoscopy }\end{array}$ & $\begin{array}{l}\text { SD Biosensor } \\
\text { Standard Q COVID- } \\
19 \text { Ag Test }\end{array}$ & NA & NA & $\begin{array}{l}3.8 \% \text { healthcare workers performing endoscopic } \\
\text { procedures were diagnosed with COVID-19; only } \\
1 \text { procedure was done on an Ag-RDT+ person. } \\
\text { Ag-RDT can be used for emergency situations in } \\
\text { the endoscopy unit. }\end{array}$ \\
\hline \multicolumn{7}{|c|}{ At-home testing } \\
\hline Martin 38 & UK & $\begin{array}{l}\text { Online acceptability survey } \\
\text { of a pilot study of daily Ag- } \\
\text { RDT at-home testing to } \\
\text { replace self-isolation for } \\
\text { asx adults }\end{array}$ & Unknown & NA & NA & $\begin{array}{l}62 \% \text { accepted daily testing. Acceptability was } \\
\text { lower in minority groups. } 88 \% \text { were confident } \\
\text { they performed the test correctly. Common } \\
\text { issues: Internet/technology access, tests being } \\
\text { unpleasant, and unclear instructions. }\end{array}$ \\
\hline Downs $^{37}$ & England & $\begin{array}{l}\text { Home-based testing of asx } \\
\text { HCWs and support staff }\end{array}$ & Innova & NA & NA & $\begin{array}{l}\text { Positivity rate was } 0.7 \% ; 1.0 \% \text { of tests were } \\
\text { invalid. Staff found testing kits easy to use. Low } \\
\text { kit failure rates and false positive results } \\
\text { supports their widespread use in asx population. }\end{array}$ \\
\hline
\end{tabular}




\begin{tabular}{|c|c|c|c|c|c|c|}
\hline Hoehl$^{\star 39}$ & Germany & $\begin{array}{l}\text { At-home testing of teachers } \\
\text { from primary/secondary } \\
\text { schools in } 3 \text { school districts } \\
\text { for } 7 \text { weeks, asx or sx }\end{array}$ & $\begin{array}{l}\text { R-Biopharm RIDA } \\
\text { QUICK SARS-CoV- } \\
2 \text { Antigen test }\end{array}$ & NA & NA & $\begin{array}{l}\text { Test positivity was } 0.19 \% \text {; Ag-RDT can be } \\
\text { performed satisfactorily unsupervised at-home } \\
\text { by the participant; medical/technical assistance } \\
\text { through hotline number should be provided. } \\
\text { Participants found it reassuring. }\end{array}$ \\
\hline Love $^{\star 40}$ & UK & $\begin{array}{l}\text { Mass testing of asx adult } \\
\text { contacts exposed to } \\
\text { COVID-19 case using self- } \\
\text { administered } \mathrm{Ag} \text {-RDTs as } \\
\text { an alternative to self- } \\
\text { isolation for } 7 \text { days post } \\
\text { exposure }\end{array}$ & Innova & NA & NA & $\begin{array}{l}\text { Test positivity: } 17.9 \% \text {. Most common motivations } \\
\text { for consenting to daily self-testing were a duty to } \\
\text { take part }(33.8 \%) \text {, the assurance of daily testing } \\
(30.4 \%) \text { and not wanting to self-isolate }(26.0 \%) \text {. }\end{array}$ \\
\hline \multicolumn{7}{|c|}{ Surveillance } \\
\hline Smith $^{41}$ & USA & $\begin{array}{l}\text { On-campus students and } \\
\text { employees of the } \\
\text { University of Illinois positive } \\
\text { for COVID-19 and their } \\
\text { close contacts tested daily } \\
\text { with Ag-RDT and RT- } \\
\text { qPCR, asx or sx }\end{array}$ & $\begin{array}{l}\text { Quidel Sofia SARS } \\
\text { Antigen Fluorescent } \\
\text { Immunoassay }\end{array}$ & $\begin{array}{l}\sim 90 \% \text { for } \\
\text { daily } \\
\text { screening } \\
\text { while } \\
\text { individual is } \\
\text { viral culture } \\
\text { positive }\end{array}$ & NA & $\begin{array}{l}\text { Sensitivity of } \mathrm{Ag}-\mathrm{RDT} \text { peaks during the period in } \\
\text { which live virus can be detected in nasal swabs. }\end{array}$ \\
\hline Kotsiou ${ }^{42}$ & Greece & $\begin{array}{l}\text { Two passive surveillance } \\
\text { programmes of entire } \\
\text { population in Volos using } \\
\text { Ag-RDT before and during } \\
\text { lockdown, asx or sx }\end{array}$ & $\begin{array}{l}\text { VivaChek Biotech } \\
\text { VivaDiag SARS- } \\
\text { CoV-2 Antigen } \\
\text { Rapid Test }\end{array}$ & NA & NA & $\begin{array}{l}\text { Test positivity: } 8 \% \text { (pre-lockdown group); } 4.7 \% \\
\text { (during lockdown group). Positive participants } \\
\text { more likely to work in the catering/food sector } \\
\text { than negative participants before the lockdown. } \\
\text { Lockdown restrictions halved the new cases. }\end{array}$ \\
\hline Winkel ${ }^{44}$ & $\begin{array}{l}\text { The } \\
\text { Netherlands }\end{array}$ & $\begin{array}{l}\text { Longitudinal cohort study } \\
\text { testing asx football players } \\
\text { and staff members of } \\
\text { professional football clubs }\end{array}$ & $\begin{array}{l}\text { Abbott PanBio } \\
\text { COVID-19 Ag Rapid } \\
\text { Test }\end{array}$ & $\begin{array}{l}85.71 \\
(67.3 \text { to } \\
96.0)\end{array}$ & $\begin{array}{l}100 \\
(99.8-100)\end{array}$ & $\begin{array}{l}\text { False-negative results mostly observed in late } \\
\text { phase of infection ( } \sim 2 \text { weeks after first positive } \\
\text { test result). }\end{array}$ \\
\hline Kriemler ${ }^{43}$ & Switzerland & $\begin{array}{l}\text { Testing of asx or sx } \\
\text { students and teachers from } \\
14 \text { primary and secondary } \\
\text { schools in Zurich with Ag- } \\
\text { RDT and PCR on two days } \\
\text { one week apart }\end{array}$ & $\begin{array}{l}\text { SD Biosensor, } \\
\text { STANDARD Q } \\
\text { COVID-19 Ag Test }\end{array}$ & NA & 99.4 & NA \\
\hline
\end{tabular}




\begin{tabular}{|c|c|c|c|c|c|c|}
\hline \multicolumn{7}{|c|}{ Prevalence survey } \\
\hline $\mathrm{Babu}^{58}$ & India & $\begin{array}{l}\text { Cross-sectional survey of } \\
\text { asx or sx adults across } \\
\text { Karnataka, tested using } \\
\text { ELISA, Ag-RDT and RT- } \\
\text { PCR }\end{array}$ & $\begin{array}{l}\text { SD Biosensor } \\
\text { STANDARD Q } \\
\text { COVID-19 Ag Test }\end{array}$ & $\begin{array}{l}\text { Symptomat } \\
\text { ic }=68.0, \\
\text { Asymptom } \\
\text { atic }=46.9\end{array}$ & NA & $\begin{array}{l}\text { Significant predictive variables for active } \\
\text { infection: headache, chest pain, wheezing, } \\
\text { rhinorrhoea, cough, sore throat, muscle ache, } \\
\text { fatigue, chills, and fever; additional predictive } \\
\text { variables: hospital outpatient attendance and } \\
\text { contact with COVID-19 patients. }\end{array}$ \\
\hline
\end{tabular}

Key: *Preprint; **Multiplex test - all other tests standalone strips.

Ag-RDT, antigen-detecting rapid diagnostic test; asx, asymptomatic; Ct, cycle threshold; HCW, healthcare worker; NP, nasopharyngeal; sx, symptomatic. 


\section{FIGURES}

\section{Figure 1. PRISMA study flowchart}

\section{Identification of studies via databases and registers}

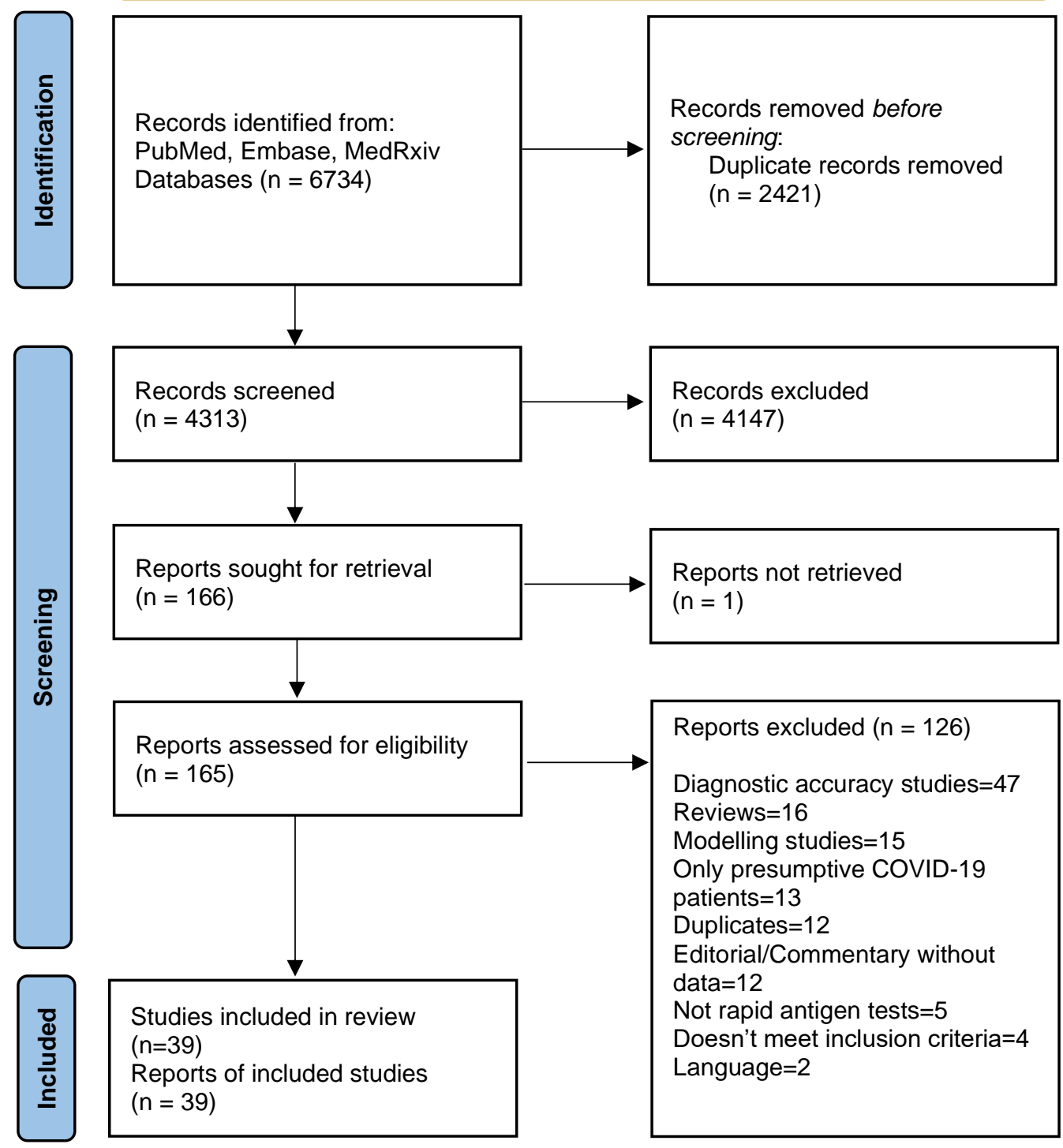


Figure 2. Range of sample sizes across each type of testing

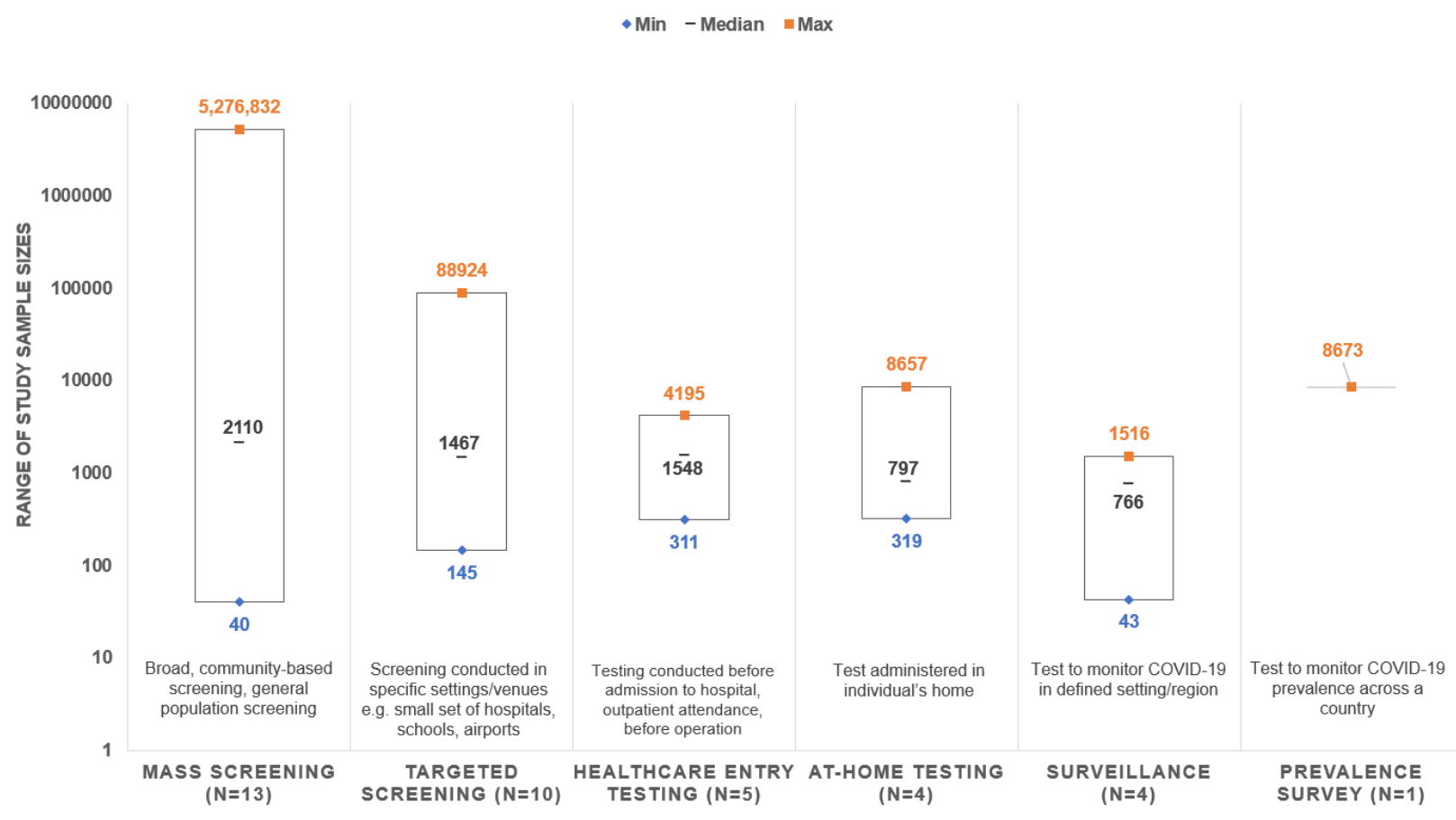

Note: Sample size was not reported for one study of targeted screening and one study of healthcare entry testing. 